\title{
Gender inequalities in the Eastern Neighbourhood region
}

\author{
Becky Carter
}

Institute of Development Studies

10 March 2021

\section{Question}

What are the structural causes and drivers of gender inequalities in the Eastern Neighbourhood region? How do these gender inequalities contribute to instability in the region?

\section{Contents}

1. Summary

2. Gender context

3. Structural causes and drivers of gender inequalities

4. Contribution of gender inequalities to instability

5. References

The K4D helpdesk service provides brief summaries of current research, evidence, and lessons learned. Helpdesk reports are not rigorous or systematic reviews; they are intended to provide an introduction to the most important evidence related to a research question. They draw on a rapid deskbased review of published literature and consultation with subject specialists.

Helpdesk reports are commissioned by the UK Foreign, Commonwealth, and Development Office and other Government departments, but the views and opinions expressed do not necessarily reflect those of FCDO, the UK Government, K4D or any other contributing organisation. For further information, please contact helpdesk@k4d.info. 


\section{Summary}

While the Eastern Neighbourhood region performs relatively well on gender equality compared with the rest of the world, women and girls continue to face systemic political and economic marginalisation and are vulnerable to gender based violence. Research on Armenia, Azerbaijan, Georgia and Moldova identifies the key underlying cause to be a set of traditional patriarchal gender norms, intersecting with conservative religious identities and harmful customary practices. These norms do not operate in isolation: the literature highlights that gender inequalities are caused by the interplay of multiple factors (with women's unequal economic resources having a critical effect), while overlapping disadvantages affect lived experiences of inequalities, creating particularly vulnerable groups. Other key factors are the region's protracted conflicts; legal reform gaps and implementation challenges; socio-economic factors (including the impact of COVID-19); and governance trends (systemic corruption, growing conservatism, and negative narratives influenced by regional geo-politics). Together these limit women and girls' empowerment; men and boys are also affected negatively in different ways, while LGBT+ people have become a particular target for societal discrimination in the region. Global evidence showing that more gender unequal societies correlate with increased instability - provides a frame of reference for the region's persistent gender inequalities.

The rapid review has two parts: first it summarises the available literature on the structural causes and more recent drivers of gender inequalities in the Eastern Neighbourhood region; second it summarises the evidence on how gender inequalities contribute to instability in this region. The report focuses on Armenia, Azerbaijan, Georgia, and Moldova, with a particular focus on the conflict areas within these countries. A companion helpdesk report looks at opportunities and initiatives supporting gender equality in the region. ${ }^{1}$

There is some academic research, and a substantial amount of grey literature by international and national organisations (including reports on human rights and the Sustainable Development Goals), on gender inequality in the Eastern Neighbourhood. Analysis of the causes of gender inequalities in the region is constrained by limited collection of gender disaggregated data, due to "low technical capacity, lack of political will and inadequate resources" (Fortuny Fillo \& Negruta, 2020: 28). Also some key issues (such as sexual and gender-based violence (SGBV)) are taboo and/or silenced by social stigma. Furthermore, this rapid review found little in-depth qualitative research into the causes of gender inequalities. There is literature highlighting the correlation between surveyed attitudes (on traditional norms) and unequal outcomes, but there appears to be little in-depth ethnographic probing of gendered experiences and causality, and how multiple factors combine to drive lived experiences of gender inequality. Research is particularly lacking from the disputed territories in the region. Exceptions include qualitative research looking indepth at women's lived experiences in Nagorno-Karabakh and surrounding areas in Armenia and Azerbaijan (Twum et al., 2019); an edited volume on women's everyday lives in war and peace in the South Caucasus (Ziemer, 2020); and older qualitative research on local perceptions and proposed solutions for skewed sex ratios at birth in the South Caucasus (Dudwick, 2015).

${ }^{1}$ Enfield, S. (2021). Promoting gender equality in the Eastern Neighbourhood region. K4D Helpdesk Report 978. Brighton, UK: Institute of Development Studies. 
This rapid review also found very little research looking at how gender inequalities contribute to instability in the region (across the building blocks of stability of inclusive power structures, economic growth and conflict resolution, effective and legitimate institutions, and supportive regional environment (Lenzen, 2016)). This is a complex issue: the linkages between individual dimensions of gender inequality and manifestations of instability are difficult to separate out from other factors; the wider cross-country literature on gender inequality and conflict highlights that causal impact has been much harder to ascertain than correlation (Birchall, 2019). There appears to be limited country research focusing specifically on the impact of gender inequalities on instability at community and national levels in the Eastern Neighbourhood. While there is a wider conflict and governance analysis literature on the drivers of conflict, it is not common for these types of analyses to look systematically at the gender dimensions of the individual drivers of instability and conflict. ${ }^{2}$

It is important to note the breadth of this two-part query, and the limitations of this review, which is rapid, relying on online searches of published material (in English), and the input of a few experts. Therefore, this summary necessarily provides an overall impression of, and highlights from, the evidence available, with illustrative (rather than comprehensive) country examples.

\section{Key findings}

- Performance on gender inequality is relatively high in the Eastern Neighbourhood region compared with the rest of the world, with some progress in recent years with legal reform across the region. However, women and girls continue to face systemic discrimination in political, economic, and family structures, and are vulnerable to SGBV.

- There has been successful civil society activism around equality (notably in Armenia's 2018 Velvet Revolution), but this has not (yet) led to concrete progress in women's political empowerment.

- In the focus countries of Armenia, Azerbaijan, Georgia and Moldova, the key underlying cause of persistent gender inequalities is a set of traditional patriarchal norms that uphold strict gender roles (women as mothers and cares; men as breadwinner and decisionmakers). These discriminatory norms intersect with conservative religious attitudes and harmful customary practices.

- Attitude surveys show prevailing attitudes aligned with traditional gender norms, in particular among men, older adults, less educated and rural populations. At the same time there are some findings of shifting attitudes in support of gender equality, particularly among women (and some men), the young, the better-educated, and urban-dwellers.

- Protracted conflicts (over Nagorno-Karabakh between Azerbaijan and Armenia; Abkhazia and South Ossetia in Georgia; and Transnistria in Moldova) affect the region's stability and possibilities for gender reform and have had gendered impacts; the large numbers of women and children displaced by the conflicts are particularly vulnerable. In the politically and economically isolated disputed territories women's rights are not prioritised, with limited civil society and prevalent SGBV (although data is lacking).

\footnotetext{
2 This mirrors the findings of a broader review of the evidence of gender as a causal factor in inter and intra state conflicts (Birchall, 2019).
} 
- Other drivers include legislative reform gaps and implementation challenges (including low rights awareness; inaccessible or ineffective justice systems; little public sector accountability); socioeconomic factors (women's economic vulnerabilities, wider economic fragilities and currently the economic impact of COVID-19, natural disasters and climate change effects); and unfavourable governance trends (systemic corruption, rising conservatism and shrinking civil space).

- Negative narratives position the gender equality agenda as "external" and "western", threatening to societies' traditional order; this links to the region's geo-political "contested" situation, characterised by polarising Russian and EU influence.

- A common theme in the literature is that gender inequalities tend to be the result of a complex set of interlinked (macro/micro) factors. One inequality can often lead to another and it is hard to distinguish drivers from practices that are being perpetuated. Women's unequal economic resources are highlighted in the literature as contributing to and/or exacerbating other gender inequalities.

- Moreover, overlapping disadvantages compound gender inequalities. Particularly vulnerable are women and girls who are displaced; from ethnic and religious minorities including Roma communities; with disabilities; living in remote and rural areas; and undocumented and stateless; and LGBT+ people.

- There is some analysis which gives an indication of the potential negative impact of gender inequalities on stability in the region. For example, research on the cost of women's unequal economic participation for the region's GDP; the striking marginalisation of women's participation in peacebuilding processes and decisionmaking; and how militarisation processes shape gender norms, encouraging men's and women's participation in/support for conflict.

- Within the scope of this rapid review, it was not possible to find research on countries in the region that looks in-depth at:

- the links between (perceptions of) gender inequalities and (perceptions of) the legitimacy of governments in the region;

- how women's marginalisation within political and economic decision-making has affected political/economic processes and outcomes;

- how the individual characteristics and trends of gender inequalities in the region's economies contribute to instability;

- links between interpersonal SGBV and impacts on stability at community or national levels;

- future contribution of sex imbalances at birth to instability;

- how gender inequalities affect the region's resilience to climate change impacts. 


\section{Gender context}

Central Asia and Europe "is among the highest performing regions" on global equality indices (Dalton, 2020: 31). Notably all four countries focused on for this report (Armenia, Azerbaijan, Georgia and Moldova) have achieved (or close to) gender equal educational completion rates. There has also been considerable progress in national legal reform to support equality and abolish discriminatory law (including introducing quotas for proportional representation; and equal divorce, inheritance, reproductive and abortion, and maternity rights)

(Organisation for Economic Co-operation and Development (OECD), 2019³: 30). However, detailed analysis shows women and girls across the region continue to face systemic discrimination, particularly in areas of economic opportunities, and voice and agency (within the family and in political structures). Key issues raised in the literature include a lack of women participating in politics; an unequal participation in the labour market; an unequal burden of unpaid care work for women; prevalence of sexual and gender-based violence (SGBV) affecting women and girls; and the persistence of harmful practices (such as child marriage and sex selective abortion) (OECD, 2019).

Intensity and forms of gender discrimination vary across the region (OECD, 2019: 33). On the 2020 World Economic Forum Global Gender Gap Index (GGI) ${ }^{4}$ Moldova has a higher ranking ( $23^{\text {rd }}$ out of 153 countries), than Georgia $\left(74^{\text {th }}\right)$, Azerbaijan $\left(94^{\text {th }}\right)$ and Armenia (98 $\left.{ }^{\text {th }}\right)$. Looking at individual dimensions of the GGI, on economic participation and opportunity, Moldova and Azerbaijan have achieved greater gender parity compared with Georgia and Armenia. Meanwhile the countries have weak performance on women's political empowerment, with Moldova performing slightly better than the others. Furthermore, studies have found higher prevalence of harmful customary practices in some countries, such as child marriage (in Georgia, Moldova, Azerbaijan ${ }^{5}$ ) and gender-biased pre-natal sex selection (in Armenia, Azerbaijan and Georgia) (OECD, 2019).

\section{Structural causes and drivers of gender inequalities}

\subsection{Discriminatory gender norms ${ }^{6}$}

Across the literature reviewed there is a common theme that pervasive discriminatory gender norms perpetuate gender inequalities in the Eastern Neighbourhood region. These norms inform prevailing "heteronormative, patriarchal, and nationalistic" stereotypes of the respective

\footnotetext{
${ }^{3}$ OECD (2019) summarises the performance on the Social Institutions and Gender Index (SIGI) of 12 Eurasian countries: Armenia, Azerbaijan, Belarus, Georgia, Kazakhstan, Kyrgyzstan, Mongolia, Republic of Moldova, Tajikistan, Turkmenistan, Ukraine and Uzbekistan.

${ }^{4} \mathrm{GGl}$ data is taken from: https://reports.weforum.org/global-gender-gap-report-2020/the-global-gender-gapindex-2020/performance-by-region-and-country/ [Accessed 22 February 2021]

${ }^{5}$ UNICEF Child marriage global database https://data.unicef.org/topic/ child-protection/child-marriage / [Accessed 23 February 2021]

6 "Gender norms are social norms defining acceptable and appropriate actions for women and men in a given group or society. They are embedded in formal and informal institutions, nested in the mind, and produced and reproduced through social interaction. They play a role in shaping women and men's (often unequal) access to resources and freedoms, thus affecting their voice, power and sense of self." (Cislaghi \& Heise, 2020: 415-416)
} 
value and roles of women and men in society (Abrahamyan et al., 2018: 54 - South Caucasus; OECD, 2019).

In the focus countries women are identified primarily as mothers and caregivers, their value tied to their caring and reproductive roles, while men are identified as the breadwinners, decisionmakers and "better politicians" (Asian Development Bank (AsDB), 2019a: viii Armenia; OECD, 2019: 26; Ziemer, 2020b: 75 - Armenia, United Nations Population Fund (UNFPA)/SCFWA7 , 2018: 10 - Azerbaijan; UN Women, 2020: 23 - Georgia; World Bank, 2017: 24 - Moldova). Consequently, women are responsible for nearly all housework and childcare even when they also work outside the home (OECD, 2019: 19; Twum et al., 2019: 24-25 Armenia, Azerbaijan, Nagorno-Karabakh).

The literature highlights the Soviet legacy behind these norms. While women obtained equal rights, and their education, economic and political participation improved in the Soviet Union, men remained dominant in the public sphere. Women ended up with a double burden of increased labour force activity on top of their domestic responsibilities. (OECD, 2019: 32; Ziemer, 2020a: 3; Ziemer, 2020b: 75).

\section{Analysis links these traditional patriarchal norms to women's current limited political and economic empowerment in the region:}

- Across Eurasia "62\% of the population believes that men make better political leaders than women do, and women occupy only $19 \%$ of parliamentary seats" (OECD, 2019: 19). In Georgia women are viewed as "unsuited for politics - a stereotypically male domain that is 'dirty' but at the same time full of privileges" (UN Women, 2020: 23). In Moldova sexist discourse is "a decisive feature" by politicians, religious and community leaders particularly during electoral campaigns, and is identified as driver of further violence against women (Mijatović, 2020: 10). Stereotypes about women's roles and leadership abilities is thought to lead to internalised low self-confidence among women to take on public decision-making roles (Abrahamyan et al., 2018: 67-68; Shahnazaryan, 2015: 12 Armenia).

- Looking at women's economic empowerment, educational enrolment parity has not translated into gender-balanced labour-market outcomes: there continues to be occupational segregation of women; a gendered subject concentration in tertiary education; a dip in female labour force participation during childbearing years; gender pay gaps; and a glass ceiling (World Bank, 2016: 1 - Armenia; OECD, 2019: 56). Quotas, parental leave schemes and childcare services are "clearly insufficient to challenge the widespread stigmatisation of women in politics or as working mothers", particularly in rural areas (OECD, 2019: 22). Women's domestic responsibilities are a key contributing factor. ${ }^{8}$

\footnotetext{
7 The State Committee of the Republic of Azerbaijan for Family, Women and Children's Affairs.

8 In Georgia 22\% of women who work part-time declare they do not have enough time to work more than they do because of family obligations, compared to 0\% of men (OECD, 2019: 46). In Azerbaijan women, particularly working mothers, "choose lower-paid public jobs to allow them to combine domestic tasks with their work duties" and are unlikely to have time to join after-work educational and networking opportunities, affecting chances of promotion (AsDB, 2019b: xii).
} 
Other dimensions of the traditional norms include the centring of ideal womanhood on "a narrow set of expectations around gender roles and female sexuality, with a strong emphasis on virginity, heterosexual marriage, and motherhood" (Twum et al., 2019: 23). This contributes to multiple gendered outcomes, including:

- control of young unmarried women and girls' mobility (Twum et al., 2019: 7-8, 24).

- (along with other factors) the continuing practice of child marriage, with highest estimated rates in Georgia, Moldova and Azerbaijan ${ }^{9}$, which in turn is closely linked with adolescent pregnancy and high female secondary school drop-out rates (UNFPA, 2014).

- gender disparities in young people's health: an incidence increase of syphilis and HIVIAIDS among young women in Moldova is linked to "insufficient [Sexual and Reproductive Health] education and discriminating stereotypes that stigmatise young women having sexual relations, leading many young women to avoid medical examination" (OECD Development Centre, 2018: 16).

- $\quad$ LGBT+ people facing widespread societal discrimination, and at times serious violence ${ }^{10}$.

Sons are valued over daughters as future economic providers for the household and/or future soldiers (in the narrative of militarised societies), who stay at home after marriage (unlike girls) and carry on the family name (Twum et al., 2019: 26; OECD, 2019: 102). This (along with other factors) is linked to pre-natal sex selection and unbalanced sex ratios at birth in Armenia, Azerbaijan and Georgia (Fortuny Fillo \& Negruta, 202011: 24), with Azerbaijan estimated to have the second highest sex ratio in the world after China (OECD, 2019: 99).

Hegemonic (ruling) masculinities reinforce "men's entitlement to engage in aggressive behaviour" (UNFPA, 2015b: 6). Violence of men against women is "a pervasive issue" across the region (OECD, 2019: 36), "rooted in gender-based discrimination, patriarchal social norms and gender stereotypes" (Fortuny Fillo \& Negruta, 2020: 20). "Domestic violence remains systemic, normalized and tolerated", considered to be a private family matter (Fortuny Fillo \& Negruta, 2020: 20).

Masculinity norms encouraging risk-taking and self-reliance lead to avoidable deaths (including from accidents and intoxication (OECD Development Centre, 2018: 16, 79 - Moldova)) with men and boys less likely to seek help for mental health issues and more likely to commit suicide" (Gough \& Novikova, 2020: ii - WHO European Region). International Men and Gender Equality Surveys (IMAGES) in Armenia, Azerbaijan, Georgia, and Moldova also found

\footnotetext{
9 The focus countries all legally allow girls to marry before the age of 18; girls in Eurasia are four times as likely as boys to be married before their 18th birthday (OECD, 2019: 44). While there are data challenges (official statistics only record registered marriages and most child marriages are unregistered) (UNFPA, 2014: 2), the share of women aged 20 to 24 years who were married or in a union before age 18 are estimated at: $14 \%$ in Georgia (2018), 12\% Moldova (2012), 11\% in Azerbaijan (2011), and 5\% in Armenia (2016) (UNICEF Child marriage global database https://data.unicef.org/topic/ child-protection/child-marriage) [Accessed 23 February 2021]

10 https://freedomhouse.org/country/georgia/freedom-world/2020 [Accessed 23 February 2021]

1 This UN Women published report takes stock of gender equality in Europe and Central Asia 25 years after the Beijing Declaration and Platform for Action.
} 
men do not tend to seek out health service providers regularly (Osipov \& Sargizova, 2016; UNFPA/SCFWA, 2018; Rakshit \& Levtov, 2020; Cheianu-Andrei et al., 2015).

These discriminatory gender norms are socialised through the family and community structures, reinforced by school (including early childhood education) and the media (World Bank, 2017: 8 - Moldova). Examples of evidence includes research showing that gender stereotypes (and domestic violence scenes) are reproduced in TV shows in Armenia (Makaryan, 2017: 18).

\section{Attitudes}

Recent surveys reveal that "inequitable attitudes and behaviors persist alongside new openness and potential for change towards equality" (Rakshit \& Levtov, 2020: 6 - Georgia).

Surveys have shown prevailing attitudes in these countries aligned with traditional gender norms. For example, OSCE (2019: v) found that in Moldova "over half of women believing that domestic violence is a private matter and nearly half holding victim-blaming views". OECD's Gender, Institutions and Development Database reports that in 2019 the percentage of women condoning domestic violence was highest in Azerbaijan, followed by Moldova, Armenia and Georgia (OECD, 2019: 97). In Armenia, 87\% of men declared they would not take paternity leave after the birth of a child (OECD, 2019: 33).

Survey data points to men, older adults, less educated and rural populations being more likely to agree with traditional discriminatory gender norms. The Pew Research Center (2017: 105, 112) survey ${ }^{12}$, found that men, older adults (aged 35 and over) and those without college degrees were more likely to think that women have a responsibility to society to bear children. Men were also more likely than women to say a wife must always obey her husband. In Moldova in 2014 " $41.1 \%$ of men state that there are moments when a woman needs to be beaten. The number of women who agree with this statement is more than 2 times lower compared to men." (Cheianu-Andrei et al., 2015: 13-14). OECD (2019: 122) found rural communities in Eurasia are more likely to uphold traditional gender norms, for example, allowing women little involvement in economic decision-making.

At the same time there are some findings of attitudes that support gender equality. For example, the Pew Research Center (2017: 115) found "clear majorities" in all surveyed countries favouring "a marriage in which both spouses work and share household responsibilities". The 2016 IMAGES survey in Armenia found that 81.7 per cent believe "A woman with the same qualifications can do as good a job as a man" (Osipov \& Sargizova, 2016: 19).

There are some findings of shifting attitudes in support of gender equality. OECD (2019: 97) reported a slightly reduced prevalence and acceptance of domestic violence by women overall in the Eurasia region from 2012 to 2019 (although between 2014 and 2019 acceptance rose in Azerbaijan and remained largely unchanged in Armenia and Georgia). Fortuny Fillo \& Negruta (2020: 22) found "the share of Armenian women stating that their families had a preference for sons declining from 45 to 13 per cent between 2011 and 2017". The 2019 IMAGES Survey in Georgia found that "more Georgians support the idea of gender equality today than six years

\footnotetext{
12 In 18 countries in Central and Eastern Europe (including Armenia, Georgia and Moldova but not Azerbaijan).
} 
ago", but the perception that the home is a woman's domain has not changed significantly (Rakshit \& Levtov, 2020: 5). OSCE (2019: iv) found that in Moldova the young, the bettereducated, and urban-dwellers said, "their friends are distinctly less likely to agree with broad notions of women's subservience to a male partner or that victims of violence are to blame for their experiences". The 2016 IMAGES Survey in Azerbaijan found that the vast majority believed more needed to be done on gender equality; however, "overall, men were more likely than women to report negative attitudes towards the promotion of rights for women" (UNFPA/SCFWA, 2018: 10). Nevertheless, the same survey found "many men ... pushing back against harmful notions of masculinity ... indicative of the positive trends in the dynamics of gender relations" (UNFPA/SCFWA, 2018: 10).

\subsection{Religious and ethnic identities and customary practices}

The Pew Research Center (2017) found that people in Orthodox-majority countries including Armenia, Georgia and Moldova - tend to hold more traditional, discriminatory views on men and women's roles in society (for example, more likely to agree that women have a social responsibility to bear children and obey their husbands). On the latter, the highest proportions agreeing were found in Armenia, followed by Georgia and then Moldova (Pew Research Center, 2017: 29). The powerful Orthodox churches tend to position themselves as champions of traditional values, including discriminatory gender norms (Nodia et al, 2018: 45-46; Ziemer, 2020: 221 - Georgia).

This rapid review was not able to find much recent literature on the contribution of religious identity to gender inequalities in majority-Muslim Azerbaijan. A 2012 survey reported that $61 \%$ of Muslims in Azerbaijan believed sons and daughters should have equal inheritance rights (Pew Research Center, 2013: 95)

Customary practices discriminate against women and girls through entrenched patrilineal kinship and inheritance systems, and traditional or religious law, upheld by informal and local courts. Key issues include unequal enjoyment of inheritance and land ownership rights, and unfair divorce processes and outcomes. In Armenia and Georgia patrilineal kinship systems and patrilocal marriages (most common in rural areas) grant daughters and/or widows a lower share of inheritance than sons and/or widowers; and limit women's land rights (OECD, 2019: 32, 75; Hohmann et al., 2014: 892). According to OECD (2019: 77) Azerbaijan and Moldova provide widows and daughters with equal inheritance rights. Meanwhile the customary practice of not officially registering marriages along with social stigma for women to seek a divorce, discriminates against women's rights to file for divorce in some communities in Armenia, Azerbaijan and Georgia (Dalton et al., 2020: 31-32; OECD, 2019: 77).

The countries all have ethnic, religious and linguistic minorities in their populations; women and girls from this group face overlapping disadvantages. There is a limited data on vulnerable groups in this region (UNICEF, 2016: 4).

- Women belonging to ethnic minorities in Georgia, particularly in rural areas - including Azeri, Armenian, Ossetian, Kist, Yazidi and Roma women - face increased vulnerability to domestic violence, child marriage and, consequently, early pregnancy and/or a high education dropout rate (UN Human Rights Council, 2016: 9). A study in Georgia found that "most older women of Avar ethnicity in Kakheti had either undergone female genital mutilation or heard of it. It also suggested that the practice remains central 
to the ethnic group's identity and might be practised clandestinely" (Fortuny Fillo \& Negruta, 2020: 22).

- The European Commissioner for Human Rights highlighted in 2020 the "persisting societal prejudices" towards Roma families in Moldova who continued to experience "substandard living conditions" with "limited access to education, employment and healthcare" (Mijatović, 2020: 6). Roma women and girls vulnerable to social exclusion, SGBV including domestic violence, child marriage, dropping out of school, lower levels of education, and trafficking for sexual exploitation and forced labour (UN Human Rights Council, 2017: 15-16; CEDAW, 2020: 8).

\subsection{Gendered impacts of conflicts}

Since the Soviet Union collapsed in 1991, the region has experienced protracted territorial disputes (Nagorno-Karabakh between Azerbaijan and Armenia, Transnistria in Moldova, and Abkhazia and South Ossetia in Georgia). These continue to be a destabilising element in the region, with fragile economies further stretched by the needs of internally displaced persons (IDPs) over the last twenty years, and most recently as a result of the 2020 open warfare in Nagorno-Karabakh.

There is some research on how political and social militarisation - notably in Armenia and Azerbaijan - has imbued gender norms with patriotic nationalism, heightening both preexisting gender role polarisation and social compliance (Shahnazarian \& Ziemer, 2018: 39). Women are valued as the mothers of future recruits, men for their role as defenders of the nation against the enemy (Ziemer, 2020b: 73-74 - Armenia). There is "a gendered hierarchy of loss" in areas in Armenia and Azerbaijan affected by Nagorno-Karabakh conflict, with women prioritising men (the economic providers/national heroes) "in their reflections of loss", while "women who are killed or injured in the conflict become invisible victims" (Twum et al., 2019: 29).

The episodes of warfare and outbreaks of violence have had gendered impacts on the local populations. In Georgia, ethnic conflicts and civil war in the early 1990s were "extraordinarily violent, with thousands of civilian casualties", with women suffering from the use of sexual violence and especially rape by soldiers on both sides "as a tool of ethnic cleansing" (Sabedashvili, 2007: 13).

As a result of these conflicts, there are large communities of marginalised IDPs in Azerbaijan, Armenia and Georgia. Often with a majority of women and children, these IDP communities face particular gendered impacts and risks. Studies of IDPs in Georgia (estimated at 301,000 in 2019, mainly displaced due to conflict over Abkhazia and South Ossetia in 1991-93 and 2008) find many "do not have sustainable accommodation and need humanitarian assistance" (Internal Displacement Monitoring Centre (IDMC), 2020). IDP women have been particularly affected by loss of family members and homes and human rights violations, and have few economic opportunities, while SGBV tends to be taboo and hidden (Šimonović, 2016: 10). Older IDP women (60\% of the displaced) were living in particularly poor economic conditions, while women in IDP centres report more SGBV, with economic stress and shame perceived to be a driver (Šimonović, 2016: 10; World Bank Group, 2017: 13). Of the 90,640 IDPs in Armenia following open warfare over Nagorno-Karabakh in September 2020, 88\% are women and children (UNHCR, 2021: 3). With IDPs facing physical, social, mental and financial impacts, host communities in Armenia were already in a "fragile socioeconomic situation", compounded by 
COVID-19 and harsh winter months (UNHCR, 2021: 3). The Government of Armenia is providing support but there are "very few prospects for employment and livelihood opportunities" (UNHCR, 2021: 3). Meanwhile the over 100,000 IDPs in Armenia who fled Azerbaijan twenty-five years ago "remain the poorest, most marginalised, and vulnerable segments of the population" facing issues of housing, education, employment, and tense relations with host communities, in rural and disadvantaged urban areas (Twum et al., 2019: 21-22).

In Azerbaijan, the Nagorno-Karabakh conflict has led to an estimated 615,000 IDPs $^{13}$, the majority of whom are women and children (AsDB, 2019: 57). There are state benefits, but some IDPs live in substandard settlements, they do not own their properties, and female IDPs lose IDP status and associated benefits if they marry non-IDP men (Twum et al., 2018: 21). The prevalence of intimate partner violence among women IDPs and refugees has been reported as 7\% higher than in other environments (Ziemer, 2020: 6). Younger IDPs are getting more education and skills training opportunities; however, this was skewed to young male IDPs "as young women were expected to devote more time to helping with domestic tasks" (AsDB, 2019: 57).

Reports highlight that authoritarian rule in the disputed territories ${ }^{14}$ allows little space for civil society activism. Women's rights tend not to be a priority, with freedom of speech restricted and little civil society activism permitted (15; Home Office, 2017: 5). Discriminatory laws affect gender equality: In Abkhazia, "A 2016 law banned abortions in all circumstances apart from prior fetal death" and there is no law to address domestic violence. ${ }^{16}$ Consensual same-sex activity is illegal in Transnistria; LGBT+ "people were subjected to official as well as societal discrimination" (U.S. Department of State, 2019: 29). SGBV is prevalent, with reports of serious problems with domestic violence and rape in Abkhazia ${ }^{17}$ and Transnistria (Home Office, 2017); "honor killings of young women accused of moral transgressions" in Abkhazia" trafficking of women for forced labour and sex work in Transnistria ${ }^{19}$; women and girls pressured to sell sexual services, including by military structures, in and around Nagorno-Karabakh (Twum et al., 2019: 27).

This rapid review was not able to find up-to-date disaggregated data on poverty and its gendered impacts in the disputed territories. There appears be little in-depth research on the causes of gender inequalities in these areas. An exception is the qualitative research undertaken in the Nagorno-Karabakh and border areas, which found highly vulnerable women and children

\footnotetext{
${ }^{13}$ https://www.internal-displacement.org/countries/azerbaijan [Accessed 5 March 2021]

14 In the 2020 Freedom of the World report, Freedom House found Abkhazia and Nagorno-Karabakh "partly free" and South Ossetia and Transnistria "not free". https://freedomhouse.org/country/abkhazia/freedom-world/2020; https://freedomhouse.org/country/nagorno-karabakh/freedom-world/2020; https://freedomhouse.org/country/south-ossetia/freedom-world/2020; https://freedomhouse.org/country/transnistria/freedom-world/2020 [Accessed 20 February 2021]

${ }^{15} \mathrm{https}$ ///kvinnatillkvinna.org/about-us/where-we-work/caucasus/georgia/; https://freedomhouse.org/country/nagorno-karabakh/freedom-world/2020 [Accessed 21 February 2021]

${ }^{16}$ https://freedomhouse.org/country/abkhazia/freedom-world/2020 [Accessed 20 February 2021]

17 https://freedomhouse.org/country/abkhazia/freedom-world/2020;

https://freedomhouse.org/country/transnistria/freedom-world/2020 [Accessed 22 February 2021]

${ }^{18} \mathrm{https}$ ://freedomhouse.org/country/abkhazia/freedom-world/2020 [Accessed 22 February 2021]

${ }^{19} \mathrm{https}: / /$ freedomhouse.org/country/transnistria/freedom-world/2020 [Accessed 22 February 2021]
} 
- with many households headed by single females - exposed to periodic violence, disruptions to basic services (water and electricity), a lack of investment in health and education, greater caring responsibilities (including for elderly relatives and grandchildren) and limited local employment (Twum et al., 2018: 18, 29; see also AsDB, 2019b: 57). This research found that conflict increased women's workload (with men away fighting or casualties of the conflict); moreover, if their husband's death is unconfirmed, a widow cannot remarry and does not get legal benefits (Twum et al., 2018: 24-25; 29).

\subsection{Discriminatory legislation and other reform gaps}

The literature highlights discriminatory legislation and other reform gaps that obstruct equal employment opportunities ${ }^{20}$ and contribute to insecure land and property rights for women across the region (OECD, 2019: 113; 127-128). A key gap is the lack of legal literacy initiatives to help women understand their land and property rights.

Notably none of the countries provides women with comprehensive legal protection from all forms of violence (OECD, 2019: 18). The literature on SGBV in the region highlights that when there has been legislative reform, implementation lags. Multiple causes include patriarchal norms; inaccessible and ineffective justice systems; lack of funding; low awareness of rights; lack of political will and lack of accountability for failures to implement reforms; and wider governance issues that affect the public sector (such as poor coordination, corruption and other inefficiencies) (UNFPA, 2015b: 8; Dugarova, 2018: 45).

Research shows there is a lot of work remaining on public sector implementation of the gender equality agenda in these countries. For example: most Georgian ministries participating in the implementation of the Women, Peace and Security agenda have no sectoral strategies or action plans on gender equality issues (UN Women, 2020: 24).

\subsection{Socioeconomic factors}

Following the collapse of the Soviet Union in 1991 all four countries suffered "profound political and economic instability" (Bak, 2020: 2), which contributed to gender inequalities. Mass-privatisation at a time of "institutional collapse and weak rule of law" led to elite wealth capture and establishment of neo-patrimonial governance (Bak, 2020:2). Men became the landholders of privatised property (OECD, 2019: 19). At the same time, there was a "rising conservatism in reaction to Soviet policies", with a "re-traditionalisation" of gender norms" (Bingham, 2016: 295; Ziemer, 2020b: 79; Ziemer, 2020a: 7). Gendered impacts included: women's economic and political marginalisation; higher poverty rates and loss of social welfare; an increase in human trafficking and domestic violence (Bingham, 2016: 295).

From the late 1990s social development improved as economies stabilised, and maternal mortality, life expectancy and labour participation rose (Bingham, 2016: 296). Now all classified as middle-income countries, while rates have fallen, poverty persists in the region. Each country is on its own economic development trajectory (from energy-exporting Azerbaijan, to agriculture dependent Armenia, Georgia and Moldova) (Khitarishvili, 2016: 2). Despite their differences,

\footnotetext{
20 For example, women are prohibited from working the same night hours and from entering certain types of jobs in Azerbaijan and Moldova (OECD, 2019: 127).
} 
across the region there are common economic challenges. World Bank (2019: xii) found that in the South Caucasus: "Difficult geographical characteristics, the relatively small size of the economies, the lack of diversification, and demographic challenges associated with emigration and low fertility rates have combined with exposure to macroeconomic risks in the external environment to create serious problems".

Barriers to women's economic empowerment, which link to patriarchal norms, include women's difficulty in accessing credit (stemming from "lack of asset ownership, collateral and financial literacy"); limited transparency in pay, promotion and reward processes; lack of free/affordable early-childcare services, particularly for low-income families; lack of flexible work arrangements for fathers and mother; limited provision (and low uptake) of paternity or parental leave benefits (OECD, 2019: 123, 128).

The literature highlights that socioeconomic factors contribute to gender inequalities:

- There continues to be a gendered poverty profile: on the whole women are more likely to be poor and unemployed than men, with female headed households particularly vulnerable to poverty (AsDB, 2019a: viii - Armenia; AsDB, 2019b: x-xi - Azerbaijan).

- Women's economic dependence on men is a key dimension in GBV risks and responses, and "a prominent obstacle" to women's access to justice, leading to recommendations of a focus on employment opportunities and economic independence in GBV prevention and response (World Bank Group, 2017: 15 - Georgia).

- Country-specific economic investment strategies and forms of development may contribute to gender inequalities. For example, AsDB (2019b: 69) detailed negative impacts on women and men of extractive industries in Azerbaijan (noise, traffic, land acquisition, and unfulfilled raised expectations of high economic benefits), while noting women "are less likely to receive economic benefits" to mitigate these negative impacts.

- With a large proportion of the workforce across the region employed in agriculture and women in rural areas proportionately more likely to be contributing family workers, "improving the productivity of agriculture will be a key to changing the gender gaps in employment composition in rural areas" (Khitarishvili, 2016: 62 - Central Asia, South Caucasus, and Western CIS).

\section{Migration}

Migration is a common coping strategy in the region. Notably "an estimated half of Moldova's 1.4 million workforce work abroad". ${ }^{21}$ Remittances from labour migration are "an indispensable source of income" for many countries in the region..$^{22}$ The impacts of migration are complex and gendered, but there is limited quantitative and longitudinal data, and few gender focused studies (Vanore \& Siegel, 2015).

Reports on the "feminisation" of labour migration in Georgia and Moldova describe "a dramatic shift in migration patterns" that has "profoundly shaken up traditional gender roles" (Hofmann \& Buckley, 2013 - Georgia; Dudwick, 2015: 21 - South Caucasus; Vanore \& Siegel,

\footnotetext{
${ }^{21}$ https://moldova.unwomen.org/en/munca-noastra/gender-equality-in-moldova [Accessed 23 February 2021]

22 https://www.bti-project.org/en/reports/regional-report-CIS.html\#pos-1 [Accessed 28 February 2021].
} 
2015 - Georgia, Moldova). Drivers include high levels of education; increasing international contacts opening up new global migration destinations; increasing divorce rates; the trend for domestic and care work in destination countries to become "gendered and ethnicised"; and an absence of local economic opportunities (Vanore \& Siegel, 2015: 5; Hofmann \& Buckley, 2013 Georgia). UNICEF $(2016: 22,28)$ found that women and girls tend to have more limited access to information on safe migration and destination work opportunities, as well as being more at risk of SGBV throughout the migration process.

In Armenia and Azerbaijan men have more commonly migrated, although in 2015 Dudwick reported increasing numbers of women migrants, particularly from Azerbaijan. AsDB (2019a: viii) found that the women left behind in Armenia take on more responsibility for unpaid work on family farms, informal home-based enterprises and childcare. Key findings in AsDB (2019a: 25) include: Women may gain more decision-making power as they become de facto heads of households; however, this role is sometimes assumed by other male relatives. Rural women commonly cannot drive or have access to a car, so their mobility is limited when their husbands migrate. With the responsibility to care for children and the elderly, these women and their households may become vulnerable to poverty if their husbands do not send remittances.

\section{COVID-19}

In 2021 the economic impacts of COVID-19 are forecasted to impoverish large numbers of people in the region, reversing some of the poverty gains made in recent years. ${ }^{23}$ Effects of the crisis will be "exacerbated by the recent collapse in oil prices" (which directly affects Azerbaijan and indirectly other countries in the region, particularly Armenia and Georgia) (OECD, 2020: 2). Armenia's socioeconomic situation is described as "fragile", compounded by the impact of COVID-19 (it has had the most severe outbreak in the South Caucasus ${ }^{24}$ ) and support required by the recent influx of people from Nagorno-Karabakh (UNHCR, 2021: 3). Research undertaken in September-November 2020 in Georgia, covering areas with IDP settlements and adjacent to the Abkhazia boundary, found an increase in women's vulnerability to domestic violence; increased family responsibilities; home-schooling challenges; and lack of access to basic services (Gamakharia, 2020).

The disputed territories' vulnerabilities have been affected by differing responses to the pandemic: one report finds South Ossetia "arguably is at greatest risk". ${ }^{25} \mathrm{~A}$ significant proportion of the population in South Ossetia is elderly and hospitals are under-resourced and medical staff untrained; meanwhile the de facto authorities' response has been slow and impeded active cooperation with the WHO and other UN agencies. ${ }^{26}$ Gamakharia (2020: 22) found pandemic-

\footnotetext{
${ }^{23}$ World Bank (2021a, 2021b) forecasts 350,000 people at risk of impoverishment in Georgia and 370,000 in Armenia.

${ }^{24}$ https://www.chathamhouse.org/2020/06/south-caucasus-states-set-diverge-further-due-covid-19 [Accessed 2 March 2021]

${ }^{25}$ https://www.crisisgroup.org/europe-central-asia/b89-covid-19-challenge-post-soviet-breakaway-statelets [Accessed 2 March 2021]

${ }^{26}$ https://www.crisisgroup.org/europe-central-asia/b89-covid-19-challenge-post-soviet-breakaway-statelets [Accessed 2 March 2021]
} 
related check-point closures in Abkhazia "practically made the people hostages ... threatening food, health, economic, physical and human security" (from research in the Gali district).

\section{Other crises}

The region also must cope with natural disasters, which have gendered outcomes, with women and girls often the most vulnerable. For example, AsDB (2019b: $x$ ) reported that in Azerbaijan "A further 68,000 persons have been internally displaced since 2009 due to natural disasters". The region is also susceptible to climate change shocks (World Bank, 2019: 74). For example, Armenia's "mountainous terrain and vulnerable ecological conditions" means it is sensitive to climate change impact, and is at risk of "more landslides, drought, and water shortages" (AsDB, 2019a: $x$ ). AsDB (2019a: $x$ ) details how women face heightened vulnerability to climate change impacts in Armenia, due to their greater domestic workload; increasing role in agriculture labour; and lower access to resources to absorb income losses.

\subsection{Governance trends}

\section{Corruption and state capture}

The region is characterised by incomplete democratisation and authoritarian government, with systemic corruption and state capture (by oligarchic interests) considered to be "the primary impediment to successful democratic transformation" (Bak, 2020: 2). Research has found that "gender inequality and corruption are closely interlinked" (Transparency International, 2014: 1). Corruption affects the poor and vulnerable most severely; women tend to be over-represented in these categories; moreover, corruption exacerbates gender disparities by undermining services and reducing resources (Transparency International, 2014: 1; UNODC, 2020: 6). However, this rapid review has found on the whole gender assessments in the Eastern Neighbourhood tend not to consider the impact of corruption on gender inequalities, while country or regional governance/corruption analyses do not consider the gender dimensions of the impact of corruption and state capture. Some relevant findings in the literature are:

- Twum et al. (2019: 20) found the Government of Azerbaijan's promotion of the cotton industry to reduce oil-dependence creates employment but also "opportunities for exploitation and corruption", especially of vulnerable IDP women and children working in the cotton fields.

- World Bank (2017: 29-30) found law enforcement and other public officials' "widespread complicity" in human trafficking in Moldova was not being addressed.

- Shahnazaryan (2015: 12) found in Armenia "elections are associated with threatening people, giving bribes, and resolving issues in a 'boy's clubs' style. Women can't and don't want to play these "games'" and therefore are excluded.

\section{Growing conservatism and shrinking civil space}

International organisations and academics report "a recent backlash against gender equality and women's rights" in the region (EU et al., 2020: 1). From a broader geographical viewpoint (Europe and Central Asia), Mann (2019: 16) identified "a resurgence of right-wing political ideologies deriving from diverse but increasingly coordinated movements, which have posed a 
challenge to women's rights". This affects progress on gender equality by the rise in social conservatism and restrictions to "public financing, support and space for women's voices" (Mann, 2019: 16). Contributing to this trend is a reported rise in religious Orthodox identities in the region, linked to social conservatism on gender norms and sexuality (Pew Research Center, 2017: 14, 64).

This rapid review found many reports providing evidence of a recent trend of "re-emerging conservatism" and "shrinking civil society space" in the focus countries. Key findings include:

- There is evidence of crackdowns on civil society space by authoritarian governments, notably in Azerbaijan ${ }^{27}$.

- Nationalist and far right groups have been increasingly targeting women and LGBT+ rights activists and organisations (Twum et al., 2019: 11; Gordon, 2020). In al the countries there are accounts of women and LGBT+ rights activists and organisations being targets of smear campaigns (including on social media), threats, harassment, and intimidation. In Georgia high-ranking officials have been involved in verbally assaulting human rights defenders (UN Women, 2020: 29).

- Gender reform has been affected: for example, the Armenian government's plans to ratify the Istanbul Convention in 2019 were dropped when nationalistic and chauvinistic groups spread disinformation and public debate turned hostile ${ }^{28}$.

- LGBT+ activism has been targeted by "sustained hostility", now "a major human rights concern" in the South Caucasus (Ziemer, 2020a: 12). Across the Eastern Neighbourhood, there is evidence of verbal abuse and hate speech against the LGBT+ community, including the use of homosexuality and broader LGBT+ issues to discredit political opponents; physical abuse; state crackdown; police mistreatment and refusal to investigate crimes against LGBT+ people ( ${ }^{29}$ - Azerbaijan; U.S. Department of State, 2019: 29 - Moldova; Ziemer, 2020a: 12 - Armenia and Georgia).

Behind these common themes the balance and momentum of reformist and conservative movements vary in each country. The literature points to opportunities for gender equality reform in Armenia, with improved political space for gender equality since the 2018 revolution and "still relatively strong" civil society and women's activism (Ziemer, 2020b: 89-90).

\section{Negative/limiting narratives}

Values of gender equality are cast as "external" and "European", threatening societies' traditional values (Abrahamyan et al, 2018: 54 - South Caucasus). This links to this "contested" region's geopolitics, in which state leaders and oligarchs "have represented and legitimised themselves as either pro-European or pro-Russian" (Bak, 2020: 3). Other institutions contribute to this narrative. For example, many clerics and church-affiliated NGOs have opposed anti-

\footnotetext{
27 https://freedomhouse.org/country/azerbaijan/freedom-world/2020 [Accessed 23 February 2021]

${ }^{28}$ https://freedomhouse.org/country/armenia/nations-transit/2020 [Accessed 23 February 2021]

${ }^{29} \mathrm{https}$ ://freedomhouse.org/country/azerbaijan/freedom-world/2020 [Accessed 23 February 2021]
} 
discrimination legislation and European integration policies as "promoting homosexuality" and "immorality" (Nodia et al, 2018: 46 - Georgia and Moldova).

Feminists report being automatically viewed as "radical" and "against the state" in Armenia (Abrahamyan et al., 2018: 53); they are perceived to be "intent on destroying traditions" (Ziemer, 2020b: 77). Women peace and reconciliation workers in Georgia reported being "looked upon by society with a measure of disdain, even to the point of them being labelled by society as 'enemies' of the State", with the local media often portraying their work "negatively or with suspicion" (UN Women, 2020: 27).

Other literature highlights that feminism in Eurasia "needs to shift its focus from considering only women to also looking at what it means to be a man. Greater incentives for men to contribute in novel ways to gender equality are indispensable, and the social contract must be reshaped to redefine masculinities" (OECD, 2019: 21).

\subsection{Interlinked, compounding factors}

Qualitative research highlights there tends to be a set of multiple and interlinked factors driving gender inequalities. For example: while neighbouring countries have similar gender norms that value sons over daughters, they do not mirror Georgia, Armenia and Azerbaijan's skewed sex ratios at birth. Research has identified a complex set of factors including traditional gender norms in conjunction with "a general availability and high acceptability of abortion and sex-determination techniques by both the medical establishment and the population, within a context of changing desired family size, low fertility, large migration flows, political instability with threat of wars, economic difficulties, and restructuring following the dismantlement of the Soviet Union" (Hohmann et al., 2014: 895; see also OECD, 2019: 102-103).

Other examples include the complex interplay of factors leading to child marriage and SGBV which exist at individual, community and societal levels, with social, political and economic dimensions (UNFPA, 2014 - Armenia, Azerbaijan, Georgia; Dugarova, 2018: 44-45). For examples of country level identification of combined factors driving intimate partner violence and child marriage in Georgia, see Šimonović $(2016: 5,7)$.

Themes in the literature include:

- It "can be difficult to disentangle cause and effect, and the trends that are driving the practice from those that are being perpetuated by it" (UNFPA, 2014:2-3). One report on gender-based violence in Moldova found GBV is a consequence of patriarchal gender norms, but widespread and systemic GBV goes on to cause further gender inequalities (OSCE, 2019: iv). Likewise, the exclusion of women from political decision-making "serves to perpetuate gender norms and biases" (World Bank, 2017: 8 - Moldova).

- There can be a "domino effect" of gender inequalities, where one leads to another, and drives further marginalisation and unequal outcomes (OECD, 2019: 54). One example is the "difficult school-to-work transition for women", as women out of work become increasingly vulnerable to continued social and labour market exclusion through lack of experience and skill-building, culminating in lesser pensions for elderly women (OECD, 2019: 54) 
- Gender inequalities intersect with and are compounded by other discriminatory factors. Human rights observers and other international organisations highlight the vulnerability of women and girls who are displaced, undocumented and stateless; live in remote and rural areas; with disabilities; are Roma or from other ethnic, religious and linguistic minorities; and LGBT+ people (UNICEF, 2016: 34; UN Human Rights Council, 2016: 11; CEDAW, 2020: 14).

\section{Contribution of gender inequalities to instability}

\subsection{Research parameters}

It was beyond the scope of this rapid review to undertake a comprehensive instability analysis. Rather the review has looked specifically for literature on how gender inequalities contribute to instability in the Eastern Neighbourhood. The following parameters helped focus the search:

1) Long term stability is understood to be achieved when "communities, states and regions are able to develop, and manage conflict ${ }^{30}$ and change peacefully" (Lenzen, 2016: 5). This review looked for literature on instability and conflict management at interpersonal, group/community, national and inter-state levels. This is informed by a normative approach (which considers human wellbeing and security to be as important as state stability) and an evidence-based understanding that violence at these different levels is interconnected. ${ }^{31}$

2) The review checked for evidence of the contribution of gender inequalities in the region to the "building blocks of stability": 1) fair power structures; 2) inclusive economic development; 3) inclusive conflict resolution mechanisms; 4) effective and legitimate institutions; 5) supportive regional environment (Lenzen, 2016).

3) The review looked for evidence from the region on key findings from existing reviews of the global evidence base which include: 1) a strong correlation between levels of gender inequality and conflict, with evidence that traditional patriarchal gender identities lead to militaristic and violent conflict approaches, and 2) emerging evidence of links between gender-based violence and conflict (Birchall, 2019 summarising Herbert, 2014a, 2014b).

\subsection{Inclusive power structures and legitimate institutions}

An evidence review undertaken to support the international Agenda for Sustainable Development found that "providing equal opportunities for women's participation in decision-making processes is beneficial for ensuring more peaceful and inclusive communities (SDG 16)" (Dugarova, 2018: 9). Women's are marginalised in decision-making in the Eastern Neighbourhood region, despite the introduction of legal measures and some incentives to promote gender-balanced political representation. There are low levels of women in national legislative bodies; decentralised levels of government; civil services; judiciaries; economic

\footnotetext{
30 This rapid review found a tendency in the literature reviewed for instability and conflict to be used interchangeably, or for instability to be understood as the precursor or underlying driver of outbreaks of conflict.

31 This approach has been developed in a forthcoming topic guide on how to analyse resilience to violence and conflict (Herbert et al., forthcoming).
} 
decision-making bodies; and security forces. Women that are present are underrepresented at senior management levels (AsDB, 2019b: 50 - Azerbaijan).

Focusing on women's political empowerment ${ }^{32}$, according to the Global Gender Gap Index Moldova has the best performance (ranked $45^{\text {th }}$ out of 153 countries) compared with Georgia $\left(94^{\text {th }}\right)$; Armenia $\left(114^{\text {th }}\right)$; Azerbaijan $\left(140^{\text {th }}\right)$. According to Freedom House, Azerbaijan "has no meaningful mechanisms to promote increased representation of women and ethnic or religious minorities"33, while OECD (2019: 147) reported local government seats are reserved for women. Armenia, Georgia and Moldova have all introduced (and in some cases raised) quotas for women on party candidate lists (and introduced financial incentives to parties that comply in Georgia and Moldova): women's parliamentary representation has risen but remained low (around 25\% in Armenia and Moldova, and lower in Georgia) (34; AsDB, 2019a: viii - Armenia). In Abkhazia, South Ossetia, Nagorno-Karabakh and Transnistria, a handful of ministerial and parliamentary seats have been held by women but generally "norms discourage women from running for office". ${ }^{35}$ Furthermore, reports on Armenia and Moldova highlight that openly LGBT+ people are put off running for public office by the harassment they receive. ${ }^{36}$

This review did not find systematic analysis of how women's marginalisation within political and economic decision-making has affected political/economic processes and outcomes, and in turn, levels/types of instability.

This rapid review did not find systematic analysis of the links between perceptions of gender inequalities and perceptions of the legitimacy of governments in the region, and the impact of this on stability. Attitude surveys have shown a mix of 1) continuing belief in and support for prevailing discriminatory gender norms, and 2) some shift in attitudes in support of more gender equal roles in society, in particular among women (but also men in some cases, as summarised earlier in this report), younger people, and those with higher levels of education and income (see more detail in section 3.1).

There is literature detailing how the exclusion of women, LGBT+ people, and other groups from decision-making has become the focus of civil society activism in the focus countries, and, in some cases, authoritarian and violent responses (see section 3.6). There have been various episodes of civil society discontent and turmoil, with recent mass movements against state corruption and capture (even for example in Azerbaijan "where space for dissent is small") showing people's "appetite for more inclusive and accountable forms of governance" (Bak, 2020: 3). Most recently in Armenia, the mobilisation of a broad range of groups advocating for greater

\footnotetext{
32 This is measured by: \% women in parliament, \% women in ministerial positions, and years with female/male head of state (last 50). https://reports.weforum.org/global-gender-gap-report-2020/dataexplorer/\#economy=ARM [Accessed 22 February 2021]

${ }^{33}$ https://freedomhouse.org/country/azerbaijan/freedom-world/2020 [Accessed 21 February 2021]

34 https://freedomhouse.org/country/armenia/freedom-world/2020;

https://freedomhouse.org/country/georgia/freedom-world/2020;

https://freedomhouse.org/country/moldova/freedom-world/2020 [Accessed 21 February 2021]

${ }^{35}$ https://freedomhouse.org/country/abkhazia/freedom-world/2020; https://freedomhouse.org/country/southossetia/freedom-world/2020; https://freedomhouse.org/country/nagorno-karabakh/freedom-world/2020; https://freedomhouse.org/country/transnistria/freedom-world/2020 [Accessed 21 February 2021]

${ }^{36} \mathrm{https}: / /$ freedomhouse.org/country/armenia/freedom-world/2020;

https://freedomhouse.org/country/moldova/freedom-world/2020 [Accessed 21 February 2021]
} 
social justice - of which gender equality was one dimension - contributed to the Velvet Revolution and, ultimately a peaceful transition (Arab \& Abrahamyan, 2019: 8). Arab and Abrahamyan (2019: 8) reported "a greater awareness among political parties of the need (and readiness of voters) for women in politics".

\subsection{Inclusive formal and informal conflict resolution mechanisms}

\section{Women's participation in peacebuilding}

United Nations and World Bank (2018: xxiii) found that "some evidence suggests that when women take leadership roles and are able to participate meaningfully in peace negotiations, the resulting agreements tend to last longer and there is greater satisfaction with the outcomes".

Peace processes in the South Caucasus are male dominated: women's voices are perceived "as insignificant and insufficient" (Abrahamyan et al., 2018: 67). In the thirty years of the Nagorno-Karabakh conflict, Twum et al. (2019: 5) found that "the number of women negotiators, witnesses and vocal peacebuilders in Armenia and Azerbaijan remains astonishingly low". There are local women's organisations and individual women peace activists working on GBV, social justice and other issues; they have no formal mandate and are "very often not linked to the official peace process" (Twum et al., 2019: 5).

Meanwhile, "Ten years after the launch of the Geneva International Discussions on the conflict in Georgia, women comprise 30 per cent of negotiators" (Fortuny Fillo \& Negruta, 2020: 32).

Analysis of the Georgian peace processes found that women's contributions "are widely recognized, but negotiating peace is left largely to men" (UN Women, 2020: 12). Barriers include: (UN Women, 2020: 9)

- "Patriarchal systems and persistent gender inequality

- Limited recognition of women's expertise and lived experience

- Shrinking political space and threats against women human rights defenders

- Funding challenges and insufficient investment in gender expertise

- Knowledge gaps

- The nature of contemporary conflict

- Tension between transformative and technocratic approaches".

A key finding was that "The short-term, sporadic and unpredictable nature of funding prevents long-term programming and its greater potential for sustainable impact", while in recent years funding has sharply declined (UN Women, 2020: 30).

\section{Patriarchal norms and militarisation}

Wider evidence reviews find "substantial evidence that traditional patriarchal gender identities lead to militaristic and violent conflict approaches" (Herbert, 2014b: 3).

Nevertheless, an important finding of Birchall (2019: 3) is that "gender is never alone as a cause or driver of conflict", it is always linked to other socio-economic factors (such as unemployment, access to land or education, generational differences, ethnic or religious differences). 
The review has found a small body of work on Armenia and Azerbaijan analysing how traditional gender norms and political and social militarisation processes shape conflict narratives and encourage men's and women's participation in and/or support for conflict.

- Ziemer (2018: 331) found that fear, grief and trauma for women in Nagorno-Karabakh created a collective identity "defined by compliance with the heightened militarization of society" that upholds patriarchal gender norms.

- Twum et al. (2019: 14) found "Militarism and nationalist sentiment are instilled in schoolchildren", with reports that men and boys from urban and rural areas all "wanted to fight without even waiting to be drafted". Meanwhile women reported "a sense of hopelessness and an inability to influence the conflict situation", while "their main priority was the struggle for everyday survival and social and economic security" (Twum et al., 2019: 14).

\subsection{Inclusive economic growth}

There is established evidence that gender equality has positive effects on promoting economic growth and labour productivity (SDG 8) (Dugarova, 2018: 9), which in turn contributes to sustainable development and peaceful societies. Herbert's (2014b: 3 ) evidence review found "countries with higher female participation in the labour force exhibit lower levels of international violence" while "better gender equality can indirectly increase a country's stability through its impact on country wealth/income (GDP)".

There is substantial evidence of women's unequal economic opportunities in the Eastern Neighbourhood. ${ }^{37}$ However, this rapid review did not find research looking systematically at how the individual characteristics and trends of gender inequalities in the region's economies contribute to instability.

There are costings of the impact of gender inequalities on economic development in the region. OECD (2019: 17) found "at the current level of discrimination, the 2017 regional income in Eurasia is reduced by $7.5 \%$, a loss of USD 39 billion" while gender parity in social institutions by 2030 "would increase regional GDP growth in Eurasia by $0.4 \%$ every year until then, representing a gain of USD 2961 per capita". The report also concluded "If Eurasian women were to participate in the labour market as men do, it would add up to USD 1.1 trillion, or $23 \%$, to the regional GDP by 2025 . About $40 \%$ of this potential increase could come from shifting women into higher-productivity sectors." (OECD, 2019: 17). For Armenia, World Bank (2016: 1) reported that "Women's lagging participation in employment and entrepreneurship results in a loss in economic output equivalent to 14 percent" of GDP in 2014

Conflict and fragility analyses find socio-economic drivers of social dissatisfaction and unrest include unequal access to land tenure, and limited job creation and high rates of (youth) unemployment (Lenzen, 2016). Armenia and Georgia have the most work to do on securing women's land ownership rights (UN Women, 2020: 19; OECD, 2019: 118-119). However, international observers express concern at the limited access of rural women to land in other

\footnotetext{
${ }^{37}$ According to the Global Gender Gap Index participation of women in the labour force is at $69.2 \%$ in Azerbaijan, 63.4\% in Georgia, 55.8\% in Armenia and 44.6\% in Moldova. https://reports.weforum.org/global-gender-gapreport-2020/the-global-gender-gap-index-2020/performance-by-region-and-country/ [Accessed 2 March 2021]
} 
countries in the region too (for example, in Moldova - CEDAW, 2020: 13). This rapid review was not able to find research specifically linking women's unequal access to land in the region to societal unrest, although this may be part of the broader gender equality agenda driving civil society activism in the region. However, UN Women (2020: 10) highlighted that "many women throughout Armenia have limited knowledge about their rights to own land, particularly among rural women".

There is work analysing demographic trends, migration and future job creation requirements for the individual countries (for example for Armenia see Honorati et al, 2019), but this rapid review was not able to find a gendered analysis forecasting the differential impacts for men and women, and concomitant contribution to (in-)stability.

\subsection{Social empowerment}

Emerging research has found countries with high levels of national violence against women and girls (such as domestic violence, female infanticide and sex-selective abortion) have been more likely to experience armed conflict than those without (Herbert, 2014b: 10).

"Eliminating all forms of gender-based violence in both public and private spheres is crucial to achieving gender equality and other goals and targets in the 2030 Agenda" including ending poverty, productive employment and economic growth, and reducing inequalities (Dugarova, 2018: 43).

Despite limited data and underreporting, the literature finds SGBV, in particular domestic violence, towards women and girls is widespread. ${ }^{38}$ However, this rapid review has not found work exploring the links between interpersonal SGBV and impacts on stability at community or national levels. There is an attempt to cost the economic impact of violence against women in Moldova, with a research study estimating that in 2015 "government spending on social assistance (e.g. counselling, shelter and food for survivors), health care and legal services for victims of domestic violence amounted to USD 1.8 million in 2015" (OECD, 2019: 47).

As summarised earlier in this report, Armenia, Azerbaijan and Georgia have had high rates of sex-selective abortion, resulting in unbalanced sex ratios at birth. UNFPA (2015a: 1 ) found that in Eastern Europe and Central Asia sex imbalances at birth "jeopardises sustainable social development and stability" forecast to have "the potential to increase human trafficking, crime, gender-based violence, and political unrest in severely affected regions". World Bank (2016: 4) reported that for Armenia the "sex imbalance may have significant demographic and economic impacts for the country. It is expected to exacerbate the slowdown in population growth, potentially by around 3\% over the next 50 years because the 'missing girls' in a generation translate into fewer women of childbearing age in the future, and encourage male emigration, which is already high". This review has not found detailed work (field-based evidence or modelling) of effects of the sex imbalance for Armenia, Azerbaijan and Georgia.

\footnotetext{
38 Across Eurasia 17\% of women are "victims of physical and/or sexual violence from an intimate partner at least once in their lifetime, and up to 46\% in Moldova" (OECD, 2019: 18-19).
} 


\subsection{Resilience}

The SDG agenda highlights the close linkages between climate change and sustainable development. Gender equality is seen as critical for "addressing climate change (SDG 13), while also strengthening resilience to climate-related disasters and managing natural resources" (Dugarova, 2018: 9).

This rapid review was not able to find comprehensive analysis of how gender inequalities affect the Eastern Neighbourhood's resilience to climate change impacts (and ultimately to the region's sustainable development and stability). The review found, some reporting on women's vulnerability to climate change impacts (as summarised previously), and some recommendations in gender assessments for gender-sensitive climate change response strategies. For example, AsDB (2019a: $x$ ) recommended in Armenia "closing gaps in social assistance outreach and ensuring access to affordable health-care to help families absorb shocks better and reduce poverty levels", with households headed by single women particularly vulnerable.

\section{References}

Abrahamyan, M., Mammadova, P., \& Tskhvariashvili, S. (2018). Women challenging gender norms and patriarchal values in peacebuilding and conflict transformation across the South Caucasus. Journal of Conflict Transformation, Caucasus Edition, 3(1), 46-72.

https://caucasusedition.net/wp-content/uploads/2019/01/CHALLENGING-GENDER-NORMS-DEALINGWITH-THE-PAST-AND-PROTECTING-THE-ENVIRONMENT-Community-Driven-Conflict-Transformation-inthe-South-Caucasus-1.pdf

Arab, C., \& Abrahamyan, M. (2019). Armenia. Country gender equality brief. UN Women. https://www.un.am/up/library/Armenia\%20Country\%20Gender\%20Equality\%20Brief.pdf

Asian Development Bank. (2019a). Armenia Country Gender Assessment. Manila: Asian Development Bank. https://dx.doi.org/10.22617/TCS190601-2

Asian Development Bank. (2019b). Azerbaijan Country Gender Assessment. Manila: Asian Development Bank. https://dx.doi.org/10.22617/TCS190569-2

Bak, M. (2020). Overview of corruption and anti-corruption in Armenia, Azerbaijan, Belarus, Georgia, Moldova and Ukraine. U4 Anti-Corruption Helpdesk. Chr. Michelsen Institute.

https://knowledgehub.transparency.org/assets/uploads/kproducts/Regional-profile-Eastern-Partnershipcountries_2020_PR.pdf

Bingham, N. (2016). Fighting for Our Cause: The Impact of Women's NGOs on Gender Policy Adoption in Four Former Soviet Republics. Politics \& Policy, 44(2), 294-318.

https://doi.org/10.1111/polp.12155

Birchall, J. (2019). Gender as a causal factor in conflict. K4D Helpdesk Report 549. Brighton, UK: Institute of Development Studies.

https://opendocs.ids.ac.uk/opendocs/bitstream/handle/20.500.12413/14393/549_Gender_as_A_Causal _Factor_in_Conflict.pdf?sequence=1\&isAllowed=y 
Cheianu-Andrei, D., Grosu, E., Perevoznic, I., \& Zaporojan-Pîrgar, A. (2015). Men and gender equality in the Republic of Moldova. Women's Law Center. https://promundoglobal.org/wpcontent/uploads/2016/03/IMAGES-Moldova-English-web.pdf

Cislaghi, B., \& Heise, L. (2020). Gender norms and social norms: differences, similarities and why they matter in prevention science. Sociology of health \& illness, 42(2), 407-422. https://doi.org/10.1111/1467-9566.13008

CEDAW. (2020). Concluding observations on the sixth periodic report of the Republic of Moldova. Committee on the Elimination of Discrimination against Women.

https://www.ecoi.net/en/file/local/2026586/N2006263.pdf

Dalton, P., Devrim, D., Blomeyer, R., \& Mut-Tracy, S. (2020). Discriminatory Laws Undermining Women's Rights. European Parliament.

https://www.europarl.europa.eu/RegData/etudes/IDAN/2020/603489/EXPO_IDA(2020)603489_EN.pdf

Dudwick, N. (2015). "Missing Women" in the South Caucasus: Local perceptions and proposed solutions.

https://www.worldbank.org/content/dam/Worldbank/Highlights\%20\&\%20Features/eca/armenia/missin g-girls-report-english.pdf

Dugarova, E. (2018). Gender equality as an accelerator for achieving the Sustainable Development Goals. UNDP \& UN Women.

https://www.undp.org/content/dam/undp/library/gender/Gender_equality_as_an_accelerator_for_achi eving_the_SDGs.pdf

Fortuny Fillo, G., \& Negruta, A. (2020). Keep the promise, accelerate the change. Taking stock of gender equality in Europe and Central Asia 25 years after Beijing. UN Women.

https://www2.unwomen.org/-

/media/field\%20office\%20eca/attachments/publications/2020/10/beijing\%20report-

min.pdf?la=en\&vs=313

Gamakharia, E. (2020). The Gender Dimension of the COVID-19 Crisis: assessing the Efficiency of Pandemic Response. Fund "Sukhumi". http://fsokhumi.ge/images/2020/12/28/Covid-19-andhuman-security-2020-ENG.pdf

Gordon, A. (2020). A New Eurasian Far Right Rising: Reflections on Ukraine, Georgia, and Armenia. Special Report January 2020. Freedom House.

https://freedomhouse.org/sites/default/files/2020-02/FarRightEurasia_FINAL_.pdf

Gough, B., \& Novikova, I. (2020). Mental health, men and culture: how do sociocultural constructions of masculinities relate to men's mental health help-seeking behaviour in the WHO European Region? Technical Report. WHO.

http://eprints.leedsbeckett.ac.uk/id/eprint/7159/1/MentalHealthMenAndCulturePV-GOUGH.pdf

Herbert, S. (2014a). Links between gender-based violence and outbreaks of violent conflict. GSDRC Helpdesk report 1169. Birmingham, UK: GSDRC, University of Birmingham.

http://www.gsdrc.org/go/display\&type=Helpdesk\&id=1169 
Herbert, S. (2014b). Links between women's empowerment (or lack of) and outbreaks of violent conflict. GSDRC Helpdesk report 1170. Birmingham, UK: GSDRC, University of Birmingham. http://www.gsdrc.org/go/display\&type=Helpdesk\&id=1170

Herbert, S., Haider, H., Lenhardt, A., \& Maguire, M. (forthcoming). How to analyse resilience to violence and conflict. Topic Guide. Birmingham, UK: GSDRC, University of Birmingham.

Hofmann, E. T., \& Buckley, C. J. (2013). Global Changes and Gendered Responses: The Feminization of Migration from Georgia. International Migration Review, 47(3), 508-538. https://www.jstor.org/stable/24542775

Hohmann, S. A., Lefèvre, C. A., \& Garenne, M. L. (2014). A framework for analyzing sexselective abortion: the example of changing sex ratios in Southern Caucasus. International Journal of Women's Health, 6, 889. https://doi.org/10.2147/IJWH.S66333

Home Office (2017). Country Policy and Information Note Moldova: Human rights in Transnistria. Version 1.0 June 2017. https://www.refworld.org/pdfid/59439c794.pdf

Honorati, M., Johansson de Silva, S., Millan, N., \& Kerschbaumer, F. (2019). Work for a better future in Armenia: An analysis of jobs dynamics. World Bank.

http://documents1.worldbank.org/curated/en/387401564380250230/pdf/Work-for-a-Better-Future-inArmenia-An-Analysis-of-Jobs-Dynamics.pdf

IDMC. (2020). Georgia. Displacement associated with Conflict and Violence. Internal Displacement Monitoring Centre. https://www.internal-displacement.org/sites/default/files/202004/GRID\%202020\%20\%E2\%80\%93\%20Conflict\%20Figure\%20Analysis\%20\%E2\%80\%93\%20GEORGIA.pdf

Khitarishvili, T. (2016). Gender Dimensions of Inequality in the Countries of Central Asia, South Caucasus, and Western CIS. Levy Economics Institute, Working Papers Series No. 858.

http://dx.doi.org/10.2139/ssrn.2727425

Lenzen, M. (2016). Building Stability Framework. Department for International Development. https://assets. publishing.service.gov.uk/media/5968990ded915d0baf00019e/UK-Aid-Connect-StabilityFramework.pdf

Makaryan, G. (2017). Barriers, remedies and good practices for women's access to justice in Armenia. Council of Europe. https://rm.coe.int/armenia-barriers-remedies-and-goodpratices $/ 168075 f d 50$

Mann, L. (2019). Regional assessment of implementation of the Beijing Declaration and Platform for Action in Europe and Central Asia. UN Women. https://www2.unwomen.org/-

/media/field\%20office\%20eca/attachments/publications/2020/03/b25\%20assessment\%20report.pdf?la= en\&vs=5437

Mijatović, D. (2020). Report following her visit to the Republic of Moldova from 9 to 13 March 2020. Commissioner for Human Rights of the Council of Europe. https://rm.coe.int/report-on-thevisit-to-moldova-from-9-to-13-march-2020-by-dunja-mijato/16809ed0e4 
Nodia, G., Cenușă, D., \& Minakov, M. (2018). Towards becoming European-style democracies. In Emerson, M. et al. (2018). The Struggle for Good Governance in Eastern Europe, London: Rowman and Littlefield Publishers. https://core.ac.uk/download/pdf/163085078.pdf\#page=20

OECD. (2019). SIGI 2019 Regional Report for Eurasia. Social Institutions and Gender Index. Paris: OECD Publishing. https://doi.org/10.1787/f6dfa21d-en

OECD. (2020). COVID-19 crisis response in Eastern Partner countries. https://read.oecdilibrary.org/view/?ref=129_129637-ttbr2Iwvsh\&title=COVID-19-Crisis-Response-in-EU-Eastern-PartnerCountries

OECD Development Centre. (2018). Youth Well-being Policy Review of Moldova. EU-OECD Youth Inclusion Project, Paris.

https://www.oecd.org/dev/inclusivesocietiesanddevelopment/Youth_Well-

being_Policy_Review_Moldova.pdf

OSCE (2019). OSCE-led survey on violence against women. Well-being and safety of women. Moldova results report. Organization for Security and Co-operation in Europe.

https://www.osce.org/files/f/documents/2/1/424979_0.pdf

Osipov, V., \& Sargizova, J. (2016). Men and gender equality in Armenia. Report on findings of the sociological survey. UNFPA. https://armenia.unfpa.org/sites/default/files/pubpdf/MEN\%20AND\%20GENDER\%20EQUALITY_Final_0.pdf

Pew Research Center (2013). The World's Muslims: Religion, Politics and Society. https://www.pewforum.org/wp-content/uploads/sites/7/2013/04/worlds-muslims-religion-politicssociety-full-report.pdf

Pew Research Center (2017). Religious belief and national belonging in Central and Eastern Europe. Pew Research Center. https://www.pewforum.org/2017/05/10/religious-belief-and-nationalbelonging-in-central-and-eastern-europe/

Rakshit, D., \& Levtov, D. (2020). Men, Women, and Gender Relations in Georgia: Public Perceptions and Attitudes. UNDP \& UNFPA Georgia. https://promundoglobal.org/wpcontent/uploads/2020/06/Men-Women-and-Gender-Relations-in-Georgia.ENG_.pdf

Sabedashvili, T. (2007). Gender and democratization: The case of Georgia 1991-2006. Heinrich Böll Foundation https://ge.boell.org/sites/default/files/gender_and_democratisation_eng.pdf

Shahnazarian, N., \& Ziemer, U. (2018). Women Confronting death: War widows' experiences in the South Caucasus. Journal of International Women's Studies, 19(2), 29-43.

https://vc.bridgew.edu/cgi/viewcontent.cgi?article=2002\&context=jiws

Shahnazaryan, G. (2015). Women's Political Participation in Armenia: Institutional and Cultural Factors. Caucasus Analytical Digest (71). https://www.files.ethz.ch/isn/189829/CAD-71.pdf

Šimonović, D. (2016). Report of the Special Rapporteur on violence against women, its causes and consequences on her mission to Georgia. https://undocs.org/A/HRC/32/42/Add.3 
Transparency International. (2014). Gender, equality and corruption: What are the linkages? Policy Brief 01/2014.

https://images.transparencycdn.org/images/2014_Policybrief1_GenderEqualityCorruption_EN.pdf

Twum, J., Jegorova-Askerova, R., \& Nemsitsveridze-Daniels, A. (Eds.) (2019). Listen to her. Gendered effects of the conflict over Nagorno-Karabakh and women's priorities for peace.

Kvinna till Kvinna Foundation. https://kvinnatillkvinna.org/wp-content/uploads/2019/07/Listen-toHer-\%E2\%80\%93-Gendered-Effects-of-the-Conflict-over-Nagorno-Karabakh-and-Womens-Priorities-forPeace.pdf

UN Women. (2020). Benchmarks, barriers and bridging the gaps: Enhancing women's meaningful participation and contribution to peace processes in Georgia.

https://georgia.unwomen.org/en/digital-library/publications/2020/07/benchmarks-barriers-andbridging-the-gaps

UNFPA. (2014). Child marriage in Eastern Europe and Central Asia: regional overview. https://eeca.unfpa.org/sites/default/files/pub-

pdf/Child\%20Marriage\%20EECA\%20Regional\%200verview.pdf

UNFPA. (2015a). Preventing Gender-biased Sex Selection in Eastern Europe and Central Asia (Issue Brief 4, 2015). https://www.unfpa.org/sites/default/files/resource-pdf/GBSS_Brief_WEB.pdf

UNFPA. (2015b). Combatting violence against women and girls in Eastern Europe and Central Asia. (Issue brief 6, 2015). https://eeca.unfpa.org/sites/default/files/pub-pdf/21770\%20Brief_web.pdf

UNFPA/SCFWA. (2018). Gender equality and gender relations in Azerbaijan: current trends and opportunities. Findings from the Men and Gender Equality Survey (IMAGES). Baku, Azerbaijan. https://promundoglobal.org/wp-content/uploads/2018/12/IMAGES-Azerbaijan-report.pdf

UNHCR. (2021). Armenia Inter-Agency Operational Update 10 December 2020 - 1 February 2021. UN High Commissioner for Refugees.

https://reliefweb.int/sites/reliefweb.int/files/resources/20201210_Interagency\%200perational\%20Upda te\%20\%233.pdf

UNICEF. (2016). Rapid Review on Inclusion and Gender Equality in Central and Eastern Europe, the Caucasus and Central Asia. Geneva: UNICEF.

https://www.unicef.org/eca/media/1061/file/Rapid_Review_On_Inclusion_Report.pdf

UNICEF. (2017). Child poverty in Europe and Central Asia region: definitions, measurement, trends and recommendations. Geneva: UNICEF. https://www.unicef.org/eca/media/3396/file

United Nations \& World Bank. (2018). Pathways for Peace: Inclusive Approaches to Preventing Violent Conflict. Washington, DC: World Bank. https://doi.org/10.1596/978-1-4648-1162-3

UNODC. (2020). Gender Brief for UNODC Staff. Mainstreaming gender in Corruption Projects/programmes. United Nations Office on Drugs and Crime.

https://www.unodc.org/documents/Gender/Thematic_Gender_Briefs_English/Corruption_brief_23_03_ 2020.pdf 
U.S. Department of State. (2019). Moldova 2019 Human Rights Report. Bureau of Democracy, Human Rights, and Labor. https://www.state.gov/wp-content/uploads/2020/02/MOLDOVA-2019HUMAN-RIGHTS-REPORT.pdf

Vanore, M., \& Siegel, M. (2015). The evolution of gendered migration trajectories from Moldova \& Georgia. Comparative Migration Studies, 3(1), 4.

https://comparativemigrationstudies.springeropen.com/articles/10.1007/s40878-015-0001-z

World Bank. (2016). Armenia Country Gender Assessment, 2016. The state of gender equality in Armenia. Washington, DC: World Bank. https://openknowledge.worldbank.org/handle/10986/26267

World Bank. (2017). Republic of Moldova - Moldova country gender action plan

(English). Washington, DC: World Bank Group.

http://documents.worldbank.org/curated/en/990771505307981800/Republic-of-Moldova-Moldovacountry-gender-action-plan

World Bank. (2021a). Poverty and welfare impacts of COVID-19 and mitigation policies in Armenia. https://reliefweb.int/sites/reliefweb.int/files/resources/Poverty-and-Welfare-Impacts-ofCOVID-19-and-Mitigation-Policies-in-Armenia.pdf

World Bank. (2021b). Poverty and welfare impacts of COVID-19 and mitigation policies in Georgia. https://reliefweb.int/sites/reliefweb.int/files/resources/Poverty-and-Welfare-Impacts-ofCOVID-19-and-Mitigation-Policies-in-Georgia.pdf

World Bank Group. (2017). Gender based violence in Georgia: Links among conflict, economic opportunities and services. Washington, DC: World Bank.

https://openknowledge.worldbank.org/handle/10986/29108

World Bank Group. (2019). South Caucasus in Motion. Washington, DC: World Bank. https://openknowledge.worldbank.org/handle/10986/31620

Ziemer, Z. (2018). "The waiting and not knowing can be agonizing": tracing the power of emotions in a prolonged conflict in the South Caucasus. International Feminist Journal of Politics, 20(3), 331-349. https://doi.org/10.1080/14616742.2018.1480900

Ziemer, U. (2020a). Introduction: Women's Everyday Lives in the South Caucasus In Ziemer, U. (Ed.) (2020). Women's Everyday Lives in War and Peace in the South Caucasus. Cham, Switzerland: Palgrave Macmillan. https://doi.org/10.1007/978-3-030-25517-6_1

Ziemer, U. (2020b). Women Against Authoritarianism: Agency and Political Protest in Armenia. In Ziemer, U. (Ed.) (2020). Women's Everyday Lives in War and Peace in the South Caucasus. Cham, Switzerland: Palgrave Macmillan. https://doi.org/10.1007/978-3-030-25517-6_1

\section{Acknowledgements}

We thank the following experts who voluntarily provided suggestions for relevant literature or other advice to the author to support the preparation of this report. The content of the report does not necessarily reflect the opinions of any of the experts consulted.

- Jenny Birchall, independent researcher 
- Siân Herbert, University of Birmingham

- Regina Jegorova-Askerova, The Kvinna till Kvinna Foundation, South Caucasus

- Olga Oliker, Crisis Group

- Ulrike Ziemer, University of Winchester

\section{Suggested citation}

Carter, B. (2021). Gender inequalities in the Eastern Neighbourhood region. K4D Helpdesk Report 977. Brighton, UK: Institute of Development Studies. DOI: 10.19088/K4D.2021.062

\section{About this report}

This report is based on twelve days of desk-based research. The K4D research helpdesk provides rapid syntheses of a selection of recent relevant literature and international expert thinking in response to specific questions relating to international development. For any enquiries, contact helpdesk@k4d.info.

K4D services are provided by a consortium of leading organisations working in international development, led by the Institute of Development Studies (IDS), with Education Development Trust, Itad, University of Leeds Nuffield Centre for International Health and Development, Liverpool School of Tropical Medicine (LSTM), University of Birmingham International Development Department (IDD) and the University of Manchester Humanitarian and Conflict Response Institute (HCRI).

This report was prepared for the UK Government's Foreign, Commonwealth and Development Office (FCDO) and its partners in support of pro-poor programmes. Except where otherwise stated, it is licensed for non-commercial purposes under the terms of the Open Government Licence v3.0. K4D cannot be held responsible for errors, omissions or any consequences arising from the use of information contained in this report. Any views and opinions expressed do not necessarily reflect those of FCDO, K4D or any other contributing organisation.

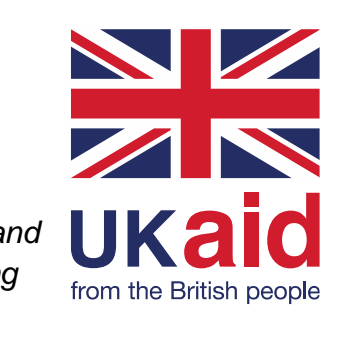

(C) Crown copyright 2021. 